\title{
PENGARUH DISIPLIN KERJA DAN PENGALAMAN KERJA TERHADAP KINERJAPEGAWAI DI KANTOR BADANPUSAT STATISTIK KABUPATENLABUHANBATU
}

\author{
Oleh : \\ Bayu Eko Broto \\ Fakultas Ekonomi dan Bisnis, Prodi Manajemen, Universitas Labuhanbatu \\ Email : mail.to.bayueb@gmail.com
}

\begin{abstract}
ABSTRAK
Penelitian ini dilakukan untuk menguji pengaruhdisiplin kerja dan pengalaman kerja terhadap kinerja pegawai di kantor Badan Pusat Statistik Kabupaten Labuhanbatu. Objek Dalam penelitian ini data dikumpulkan melalui metode kuesioner dengan mengunakan metode total sampling untuk mengetahui tanggapan responden terhadap masing-masing variabel. Teknik analisis data yang digunakan adalah regresi linier berganda dan uji hipotesis menggunakan uji $\mathrm{t}$ untuk menguji koefisien regresi parsial serta uji $\mathrm{F}$ untuk menguji keberartian pengaruh secara bersama-sama. Selain itu juga dilakukan uji asumsi klasik yang meliputi uji normalitas, uji multikolinearitas dan uji heteroskedastisitas. Berdasarkan uji asumsi klasik tidak ditemukan variabel yang menyimpang. Hal ini menunjukkan data yang tersedia telah memenuhi syarat menggunakan model persamaan regresi linier berganda.

Dalam penelitian ini diperoleh persamaan regersi : $\mathrm{Y}=29.270+0.499 \mathrm{X}_{1}+0.352 \mathrm{X}_{2}+$ $0.329 \mathrm{X}_{3}+\varepsilon$. Hasil penelitian ini menunjukkan bahwa variabel disiplin kerja dan pengalaman kerja menunjukkan pengaruh positif dan signifikan terhadap kinerja pegawai baik secara parsial maupun simultan. Kemampuan prediksi dari ketiga variabel tersebut terhadap kinerja pegawai dalam penelitian ini sebesar $46.4 \%$, sedangkan sisanya $53,6 \%$ dipengarui oleh faktor lain yang tidak dimasukkan ke dalam model penelitian.
\end{abstract}

\section{Kata kunci : Disiplin Kerja, Pengalaman Kerja, Kinerja Pegawai}

\section{PENDAHULUAN}

\section{Latar Belakang Masalah}

Peran Sumber Daya Manusia (SDM) dalam suatu organisasi memiliki kedudukan yang penting pada pelaksanaan proses kerja organisasi dan pencapaian tujuan organisasi. Dalam pelaksanaannya, manusia dalam organisasi ini menjadi elemen utama dibandingkan dengan sumber daya yang lain. Tanpa adanya sumber daya manusia, sumber daya yang lain tentunya tidak akan bisa dimanfaatkan.
Meskipun banyak faktor yang mempengaruhi organisasi seperti mesinmesin modern, modal yang kuat, teknologi dan sistem yang canggih, tetapi tanpa adanya manusia yang menangani dan mengelolanya tidak akan berarti bagi perkembangan organisasi.

Sumber daya manusia adalah orang-orang yang merancang dan merumuskan seluruh strategi dan tujuan organisasi. Tanpa orang-orang yang memiliki keahlian atau kompetensi maka 
mustahil bagi organisasi untuk mencapai tujuannya. Sumber daya manusia inilah yang membuat sumber daya lainnya dapat berjalan. Banyaknya keunggulan yang dimiliki organisasi, tidak akan dapat memaksimalkan produktivitas tanpa adanya komunitas pegawai yang berkeahlian, kompeten, berdedikasi tinggi terhadap organisasi serta memiliki kinerja yang optimal (Samsudin, 2009).

Kinerja (performance) dapat diartikan sebagai pencapaian hasil kerja sesuai dengan aturan dan standar yang berlaku pada masing-masing organisasi. Simamora (2008) menyatakan bahwa kinerja merupakan suatu persyaratanpersyaratan tertentu yang akhirnya secara langsung dapat tercermin dari output yang dihasilkan baik yang berupa jumlah maupun kualitasnya. Output yang dihasilkan menurut Simamora dapat berupa fisik maupun nonfisik yang menyebutnya berupa karya, yaitu suatu hasil/pekerjaan baik berupa fisik/material maupun nonfisik maupun nonmaterial.

Seorang pegawai dituntut untuk mengerjakan tugasnya dengan baik. Keberhasilan mereka dalam pemberian pelayanan kepada masyarakat ditentukan oleh penilaian terhadap kinerjanya. Penilaian tidak hanya dilakukan untuk membantu mengawasi sumber daya organisasi namun juga untuk mengukur tingkat efisiensi penggunaan sumber daya yang ada dan mengidentifikasi hal-hal yang perlu diperbaiki. Penilaian terhadap kinerja merupakan faktor penting untuk meningkatkan kinerja pegawai. Bagianbagian yang menunjukkan kemampuan pegawai yang kurang maksimal dapat diidentifikasi, diketahui sehingga dapat ditentukan strategi dalam meningkatkan kinerjanya.
Untuk menciptakan kinerja yang tinggi, dibutuhkan adanya peningkatan kerja yang optimal dan mampu mendayagunakan potensi sumber daya manusia yang dimiliki oleh pegawai guna menciptakan tujuan organisasi, sehingga akan memberikan kontribusi positif bagi perkembangan organisasi. Selain itu, organisasi perlu memperhatikan berbagai faktor yang dapat mempengaruhi kinerja pegawai, dalam hal ini diperlukan adanya peran organisasi dalam meningkatkan kinerja yang efektif dan efisien, guna mendorong terciptanya sikap dan tindakan yang profesional dalam menyelesaikan pekerjaan sesuai dengan bidang dan tanggung jawab masing-masing.

Salah satu faktor yang berperan penting dalam menciptakan peningkatan kinerja adalah disiplin kerja. Disiplin kerja adalah suatu alat yang digunakan para manajer untuk berkomunikasi dengan karyawan agar mereka bersedia untuk mengubah suatu perilaku serta sebagai suatu upaya untuk meningkatkan kesadaran dan kesediaan seseorang menaati semua peraturan perusahaan dan norma-norma sosial yang berlaku (Rivai, 2008).

Disiplin kerja yang baik mencerminkan besarnya rasa tanggung jawab seseorang terhadap tugas-tugas yang diberikan kepadanya. Dengan disiplin kerja pegawai yang tinggi, akan mampu mencapai efektivitas kerja yang maksimal, baik itu disiplin waktu, tata tertib atau peraturan yang telah ditetapkan oleh organisasi. Peraturan sangat diperlukan untuk memberikan bimbingan dan penyuluhan bagi pegawai dalam menciptakan tata tertib yang baik di instansi dimana dengan tata tertib yang baik, maka semangat kerja, moril kerja, 
efisiensi dan efektivitas kerja pegawai akan meningkat (Hasibuan, 2008:194).

Disamping disiplin kerja, pengalaman kerja juga sangat menentukan. Pengalaman kerja pegawai mencerminkan tingkat penguasaan pengetahuan dan keterampilan yang dimiliki seorang pegawai dalam bekerja yang dapat diukur dari masa kerja dan jenis pekerjaan yang pernah dikerjakan pegawai. Masa kerja pegawai yang semakin lama dengan jumlah pegawai semakin sedikit menyebabkan kurangnya pengalaman kerja Pegawai. Selain itu, Latar belakang pendidikan yang beragam menyebabkan kurangnya tingkat pengetahuan Pegawai dalam bidang masing-masing, sehingga Pegawai kurang berpengalaman dalam melaksanakan tupoksi pekerjaannya.

Kompetensi yang dimiliki pegawai sangat penting dalam meningkatkan kinerja pegawai. Kompetensi mencerminkan kemampuan pegawai untuk melaksanakan pekerjaan yang dibebankan kepadanya dan menjalin kerjasama serta berinteraksi dengan orang lain dalam bekerja untuk mencapai tujuan organisasi. Kompetensi sosial yang rendah terlihat dari kurangnya kemampuan pegawai untuk melaksanakan pekerjaannya. Selain itu, kurangnya kemampuan Pegawai untuk memelihara hubungan kerja sama dengan pegawai-pegawai yang lain mengakibatkan kurang efektif dan efisiennya dalam penyelesaian pekerjaan.

Berdasarkan observasi dilapangan, peneliti masih menemukan ada permasalahan yang berhubungan dengan disiplin kerja dan pengalaman kerja, yaitu masih adanya pegawai yang santai saat jam kerja sedang berlangsung tanpa aktivitas yang berarti, masih adanya pegawai yang sering datang terlambat, masih adanya pegawai yang lebih mementingkan urusan pribadi disaat jam kerja, masih adanya kesenjangan yang terjadi misalnya masih kurangnya komunikasi dengan rekan kerjanya dalam kegiatan kantor sehari-hari, masih adanya pegawai yang kurang semangat dalam melaksanakan pekerjaannya, bahkan kurang puasnya jaminan hari tua, adanya pegawai yang masih belum memahami apa pekerjaan yang sesuai dengan kemampuannya, masih adanya pegawai yang memiliki pengalaman kerja yang minim sehingga pekerjaan yang dibebankan kepadanya tidak dapat dilakukan dengan maksimal serta pelayanan yang diberikan oleh sebagian masyarakat dianggap belum maksimal.

Dengan melihat dan memperhatikan uraian-uraian tersebut di atas, maka peneliti tertarik untuk melakukan penelitian dengan judul "Pengaruh Disiplin Kerja dan Pengalaman Kerja Terhadap Kinerja Pegawai di Kantor Badan Pusat Statistik Kabupaten Labuhanbatu".

\section{TINJAUAN PUSTAKA}

\section{Disiplin Kerja}

Kedisiplinan merupakan fungsi operasional manajemen sumber daya manusia yang terpenting karena semakin baik disiplin kerja pegawai, semakin baik kinerja yang dapat dicapai.Tanpa disiplin yang baik, sulit bagi organisasi untuk mencapai hasil yang optimal.Kedisiplinan merupakan faktor yang utama yang diperlukan sebagai alat peringatan terhadap pegawai yang tidak mau berubah sifat dan perilakunya. Sehingga seorang pegawai dikatakan memiliki disiplin yang baik jika pegawai tersebut memiliki rasa tanggung 
jawab terhadap tugas yang diberikan kepadanya

Berikut adalah pengertianpengertian disiplin kerja menurut para ahli diantaranya yaitu :

Heidjrachman dan Husnan, (2008) mengungkapkan "Disiplin adalah setiap perseorangan dan juga kelompok yang menjamin adanya kepatuhan terhadap perintah" dan berinisiatif untuk melakukan suatu tindakan yang diperlukan seandainya tidak ada perintah".

Menurut Davis (2007) "Disiplin adalah tindakan manajemen untuk memberikan semangat kepada pelaksanaan standar organisasi, ini adalah pelatihan yang mengarah pada upaya membenarkan dan melibatkan pengetahuan-pengetahuan sikap dan perilaku pegawai sehingga ada kemauan pada diri pegawai untuk menuju pada kerjasama dan prestasi yang lebih baik".

Menurut Hasibuan (2009:444) bahwa : "Disiplin kerja adalah kesadaran dan kerelaan seseorang dalam menaati semua peraturan perusahaan dan normanorma sosial yang berlaku."

Sedangkan menurut Rivai (2008:825) bahwa : "Disiplin kerja adalah suatu alat yang dipergunakan para manajer untuk berkomunikasi dengan karyawan agar mereka bersedia untuk mengubah suatu perilaku serta sebagai suatu upaya untuk meningkatkan kesadaran dan kesedian seorang dalam memenuhi segala peraturan perusahaan."

Menurut Singodimenjo dalam Sitrisno (2011:86) bahwa : "Disiplin adalah sikap kesediaan dan kerelaan seseorang untuk mematuhi dan mentaati norma-norma peraturan yang berlaku di sekitarnya."
Tindakan pendisiplinan kepada pegawai haruslah sama pemberlakuaanya. Disini tindakan disiplin berlaku bagi semua, tidak memilih, memilah dan memihak kepada siapapun yang melanggar akan dikenakan sanksi pendisiplinan yang sama termasuk bagi manajer atau pimpinan, karena pimpinan harus memberi contoh terhadap para bawahannya.

Menurut Mangkunegara (2011:129) mengemukakan bahwa terdapat tiga bentuk disiplin kerja yaitu:

1. Disiplin preventif

Merupakan suatu upaya untuk menggerakan pegawai untuk mengikuti dan mematuhi pedoman kerja, aturan aturan yang telah digariskan oleh perusahaan.

2. Disiplin korektif

Merupakan suatu upaya untuk menggerakan pegawai dalam suatu peraturan dan mengarahkan untuk tetap mematuhi peraturan sesuai dengan pedoman yang berlaku pada perusahaan.

3. Disiplin progresif

\begin{tabular}{llr} 
Merupakan & kegiatan yang \\
memberikan hukuman-hukuman \\
yang lebih & \multicolumn{1}{c}{ berat terhadap } \\
pelanggaran-pelanggaran & yang \\
berulang. & &
\end{tabular}

Sedang indikator yang digunakan untuk menilai tingkat kedisiplinan seorang pegawai menurut Singodimejo dalam Sutrisno (2011) adalah sebagai berikut:

1. Taat terhadap aturan waktu Dilihat dari jam masuk kerja, jam pulang, dan jam istirahat yang tepat waktu sesuai dengan aturan yang berlaku di perusahaan.

2. Taat terhadap peraturan perusahaan 
Peraturan dasar tentang cara berpakaian, dan bertingkah laku dalam pekerjaan.

3. Taat terhadap aturan perilaku dalam pekerjaan

Ditunjukan dengan cara-cara melakukan pekerjaan-pekerjaan sesuai dengan jabatan, tugas dan tanggung jawab serta cara berhubungan dengan unit kerja lain.

4. Taat terhadap peraturan lainnya diperusahaan

Aturan tentang apa yang boleh dan apa yang tidak boleh dilakukan oleh para pegawai dalam perusahaan.

\section{Pengalaman Kerja}

Pengalaman kerja pegawai dalam melaksanakan tugas pada sebuah organisasi sangatlah penting peranannya. Seorang pegawai yang memiliki pengalaman kerja lebih banyak tentu akan lebih mengerti apa yang harus dilakukan ketika menghadapi sebuah masalah yang muncul. Selain itu pegawai tersebut akan lebih cepat dalam bekerja dan tidak harus beradaptasi dengan tugas yang dijalankan karena sudah memiliki pengalaman. Sehingga organisasi akan lebih mudah mencapai tujuan organisasi karena didukung oleh para pegawai yang sudah berpengalaman di bidangnya masingmasing.

Pengalaman kerja adalah tingkat penguasaan pengetahuan dan keterampilan yang dimiliki pegawai dalam bekerja yang dapat diukur dari masa kerja dan jenis pekerjaan yang pernah dikerjakan karyawan selama periode tertentu. Hal ini sejalan dengan teori yang dinyatakan Robbins dan Timothy (2008) bahwa pengalaman kerja didasarkan pada pengetahuan dan keterampilan yang dimiliki karyawan.

Pengalaman (experience)menurut Cascio dalam Nasaruddin (2008) adalah suatu faktor untuk menilai seberapa lama seseorang mengetahui/bertukar pengetahuan dengan orang lain untuk bisa melaksanakan pekerjaannya secara efektif. Pengalaman kerja merup akan peristiwa yang pernah dialami dan ditanggung oleh individu dalam menjalani kehidupannya khususnya dalam mencari nafkah (Wardayati, 2008:4).

Menurut Hariandja (2008) menyatakan, "Pengalaman kerja adalah suatu pekerjaan atau jabatan yang pernah diduduki sebelumya selama kurun waktu tertentu". Selain itu ada pendapat lain menurut Hasibuan (2009:55), "Pengalaman kerja seorang pelamar hendaknya mendapat pertimbangan utama dalam proses seleksi. Orang yang berpengalaman merupakan calon karyawan yang siap pakai".

Sedangkan Pengalaman kerja menurut pendapat Alwi (2005) "Masa kerja atau pengalaman kerja adalah jangka waktu atau lamanya seseorang bekerja pada suatu instansi, kantor atau sebagainya".

Dari beberapa pendapat diatas dapat disimpulkan bahwa pengalaman kerja adalah tingkat peguasaan pengetahuan serta keterampilan seseorang yang dapat diukur dari masa kerja seorang. Sehingga semakin lama seseorang bekerja semakin bertambah pengalamannya terhadap pekerjaannya. Dengan banyaknya pengalaman kerja yang dimiliki seseorang pekerja maka orang tersebut akan lebih menguasai pekerjaannya, sehingga dapat menyelesaikan pekerjaannya dengan baik 
ini berarti orang tersebut mempunyai efektifitas kerja yang baik.

Sehingga banyak organisasi dan perusahaan yang dalam perekrutan pegawainya dipilih yang sudah mempunyai pengalaman kerja, karena pengalaman kerja seseorang dianggap sebagai salah satu kualitas tenaga kerja, sehingga tenaga kerja yang berpengalaman sangat dibutuhkan dalam dunia usaha. Banyaknya pengalaman kerja seseorang ditentukan oleh masa kerja atau lamanya seseorang itu bekerja.

Adapun yang dapat dijadikan indikator pengalaman kerja seorang pegawai adalah lama kerja atau masa kerja, yaitu pengalaman kerja seorang pegawai pada jangka waktu tertentu dengan ukuran tahun pada organisasi atau perusahaan tempat dia bekerja sebelumnya.

Hal ini sejalan dengan pendapatMartoyo (2007) dan Alwi (2005) menyatakan bahwa pengalaman kerja didasarkan pada masa kerja atau jangka waktu karyawan dalam bekerja. Sedangkan menurut Syukur (2006) dan Hariandja (2008) menyatakan bahwa pengalaman kerja didasarkan pada jenis pekerjaan yang pernah dikerjakan selama periode tertentu.

Adapun menurut Marinus $d k k$. dalam Herliansyah $d k k$. (2006) menyatakan bahwa secara spesifik pengalaman dapat diukur dengan rentang waktu yang telah digunakan terhadap suatu pekerjaan atau tugas $(j o b)$.

Dimensi pengalaman kerja yang digunakan di dalam penelitian ini mengacu pada pendapat yang disampaikan Foster (2007) bahwa pengukuran pengalaman kerja dapat dilihat dari lama waktu atau masa kerja, tingkat pengetahuan dan keterampilan yang dimiliki, serta jenis pekerjaan.
Sedangkan menurut Handoko (2009) ada beberapa hal juga untuk menentukan berpengalaman tidaknya seorang pegawai yang sekaligus sebagai indikator pengalaman kerja yaitu:

a. Lama waktu/masa kerja

Ukuran tentang lama waktu atau masa kerja yang telah ditempuh seseorang dapat memahami tugas-tugas suatu pekerjaan dan telahmelaksanakan dengan baik.

b. Tingkat pengetahuan dan ketrampilan yang dimiliki

Pengetahuan merujuk pada konsep, prinsip, prosedur, kebijakan atau informasi lain yang dibutuhkan oleh karyawan. Pengetahuan juga mencakup kemampuan untuk memahami dan menerapkan informasi pada tanggung jawab pekerjaan. Sedangkan ketrampilan merujuk pada kemampuan fisik yang dibutuhkan untuk mencapaiatau menjalankan suatu tugas atau pekerjaan

c. Penguasaan terhadap pekerjaan dan peralatan

Tingkat penguasaan seseorang dalam pelaksanaan aspek-aspek tehnik peralatan dan tehnik pekerjaan.

Dari uraian tersebut dapat diketahui, bahwa seorang yang berpengalaman akan memiliki gerakan yang mantap dan lacar, gerakannya berirama, lebih cepat menanggapi tandatanda, dapat menduga akan timbulnya kesulitan sehingga lebih siap menghadapinya, dan bekerja dengan tenang serta dipengaruhi faktor lain yaitu: lama waktu/masa kerja seseorang, tingkat pengetahuan atau ketrampilan yang telah dimiliki dan tingkat penguasaan terhadap pekerjaan dan peralatan. 


\section{Kinerja Pegawai}

Secara garis besar, kinerja dapat dipahami sebagai hasil kerja yang dapat dicapai oleh seseorang atau sekelompok orang dalam suatu organisasi sesuai dengan wewenang dan tanggung jawab masing-masing, guna mencapai tujuan organisasi yang bersangkutan secara legal, tidak melanggar hukum, dan sesuai dengan moral maupun etika.

Waldman (2006) mendefinisikan "Kinerja sebagai gabungan perilaku dengan prestasi dari apa yang diharapkan dan pilihannya atau bagian syarat-syarat tugas yang ada pada masing-masing individu dalam organisasi".

Sedangkan menurut Mangkunegara (2011) "Kinerja dapat didefinisikan sebagai hasil kerja secara kualitas dan kuantitas yang dapat dicapai oleh seorang pegawai dalam melaksanakan tugas sesuai dengan tanggungjawab yang diberikan kepadanya".

Rivai (2008) mengemukakan kata kinerja, jika dilihat dari asal katanya adalah terjemahan dari kata performance yang berasal dari akar kata to perform yang berarti melaksanakan atau menyempurnakan tanggung jawab. Kinerja adalah hasil atau tingkat keberhasilan seseorang secara keseluruhan selama periode tertentu di dalam melaksanakan tugas dibandingkan dengan berbagai kemungkinan seperti standar hasil kerja, target atau sasaran atau kriteria yang telah ditentukan terlebih dahulu dan telah disepakati bersama.

Cascio dalam Nasaruddin (2008) mengatakan bahwa "Kinerja merupakan prestasi karyawan dari tugas-tugas yang telah ditetapkan". Soeprihanto (2007); mengatakan bahwa "Kinerja merupakan hasil pekerjaan seorang karyawan selama periode tertentu dibandingkan dengan berbagai kemungkinan, seperti standar, target/sasaran maupun kriteria yang telah ditentukan terlebih dahulu dan telah disepakati bersama".

Bernadin dan Russel (2010) mendefinisikan "Kinerja sebagai catatan keberhasilan yang dihasilkan dari fungsi suatu pekerjaan tertentu atau kegiatan selama kurun waktu tertentu". Sedangkan Whitmore (2007) mengemukakan bahwa "Kinerja dengan asal kata 'kerja' berarti aktivitas yang dilakukan oleh seseorang atau organisasi dalam menjalankan tugas yang menjadi pekerjaannya".

Kinerja merupakan suatu perbuatan, suatu prestasi, atau penampilan umum dari keterampilan. Mangkunegara (2011), mengatakan bahwa istilah "Kinerja berasal dari kata job performance atau actual performance, yaitu unjuk kerja atau prestasi yang sesungguhnya dicapai oleh seseorang dalam melaksanakan tugas sesuai dengan tanggung jawab yang diberikan kepadanya".

Seseorang akan selalu mendambakan penghargaan terhadap hasil pekerjaannya dan mengharapkan imbalan yang adil. Penilaian kinerja perlu dilakukan seobyektif mungkin karena akan memotivasi karyawan dalam melakukan kegiatannya. Di samping itu, penilaian kinerja dapat memberikan informasi untuk kepentingan pemberian gaji, promosi dan pengawasan terhadap perilaku karyawan. John Suprihanto (2008) menyatakan bahwa penilaian kinerja (performance appraisals) merupakan suatu sistem yang digunakan untuk menilai dan mengetahui sejauh mana karyawan telah melaksanakan pekerjaannya masingmasing secara keseluruhan. Menurut John 
Suprihanto (2008), terdapat 7 manfaat dari penilaian kinerja, antara lain :

1. Meningkatkan keterampilan dan kemampuan karyawan secara rutin.

2. Sebagai dasar perencanaan bidang personalia, khususnya pada penyempurnaan kondisi kerja, peningkatan mutu dan hasil kerja.

3. Sebagai dasar pengembangan dan pendayagunaan karyawan seoptimal mungkin sehingga dapat diarahkan jenjang atau perencanaan kariernya, kenaikan pangkat, dan kenaikan jabatan.

4. Mendorong terciptanya hubungan timbal balik yang sehat antara atasan dan bawahan.

5. Mengakui kondisi perusahaan secara keseluruhan di bidang personalia, khususnya kinerja karyawan pada pekerjaannya.

6. Secara pribadi, bagi individu pegawai, dapat mengidentifikasi kekuatan dan kelemahan masing-masing sehingga dapat memacu perkembangan. Bagi atasan sebagai penilai, akan lebih memperhatikan dan mengenal karyawan agar dapat membantu serta memotivasi pegawai dalam bekerja.

7. Hasil penelitian pelaksanaan pekerjaan dapat bermanfaat bagi proses penilaian dan pengembangan secara keseluruhan.

Kemudian tujuan kinerja menurut Rivai dan Basri (2008:14):

1. Kemahiran dari kemampuan tugas baru diperuntukan untuk perbaikan hasil kinerja dan kegiatannya.

2. Kemahiran dari pengetahuan baru dimana akan membantu karyawan dengan pemecahan masalah yang kompleks atas aktivitas membuat keputusan pada tugas.
3. Kemahiran atau perbaikan pada sikap terhadap teman kerjanya dengan satu aktivitas kinerja.

4. Target aktivitas perbaikan kinerja.

5. Perbaikan dalam kualitas atau produksi.

6. Perbaikan dalam waktu atau pengiriman.

Yuwalliatin (2006) mengatakan bahwa kinerja diukur dengan instrumen yang dikembangkan dalam studi yang tergabung dalam ukuran kinerja secara umum kemudian diterjemahkan kedalam penilaian perilaku secara mendasar, meliputi:

1. kuantitas kerja

2. kualitas kerja

3. pengetahuan tentang pekerjaan

4. pendapat atau pernyataan yang disampaikan

5. perencanaan kegiatan

\section{METODE PENELITIAN}

\section{Teknik Pengumpulan Data}

Teknik pengumpulan data yang dliakukan dalam penelitian ini adalah

1. Observasi

Observasi dilakukan dengan pengamatan secara langsung dan pencatatan mengenai kejadian-kejadian yang diselidiki untuk mendapatkan data.

2. Kuesioner

Data diperoleh dengan memberikan daftar pertanyaan kepada responden. Dan jawaban dari setiap pertanyaan tersebut ditentukan pointnya melalui model skala Likert, dengan skala 1 sampai dengan 5. Angka 5 menunjukkan sangat puas atau setuju atau dan skala 3 menunjukkan netral, sedangkan skala 1 menunjukkan sangat tidak puas atau tidak setuju. 
3. Wawancara

Wawancara dengan atasan dan para pegawai untuk mendapatkan informasi yang dibutuhkan, yang berkaitan dengan motivasi, disiplin kerja, pengalaman kerja dan kinerja pegawai.

4. Studi pustaka (Library Research)

Studi pustaka dimana data yang diperoleh dari fakta-fakta berupa pendapat dan karya para ahli yang didapat dari buku-buku dan jurnal. Selain itu juga adapun data-data pendukung yang didapat melalui internet.

\section{Jenis dan Sumber Data}

Jenis data dalam penelitian ini adalah data kualitatif dan sumber data yang dikumpulkan dalam penelitian ini yaitu :

1. Data Primer

Data primer merupakan data yang langsung diambil dari obyek penelitian oleh peneliti. Data diperoleh melalui observasi berupa kegiatan yang berhubungan dengan pembahasan, kuesioner dan juga wawancara dengan pihak-pihak terkait.

2. Data Sekunder

Data sekunder merupakan data yang didapat tidak secara langsung dari objek penelitian. Peneliti mendapatkan data yang sudah jadi yang dikumpulkan oleh pihak lain dengan berbagai cara dapat berupa buku dan majalah ilmiah yang sesuai dengan permasalahan.

\section{Metode Analisis Data}

\section{Uji Penyimpangan Klasik}

Tahap analisis awal untuk menguji model yang digunakan dalam penelitian ini, agar bisa diperoleh model regresi yang bisa dipertanggungjawabkan dan tidak bias atau disebut BLUE (Best, Linear, Unbiased, Estimator) maka dilakukan uji normalitas, autokorelasi, multikolinearitas dan heteroskedastisitas.

\section{Uji Multikolinearitas}

Uji multikolinieritas dilakukan untuk menguji apakah dalam model regresi ditemukan adanya korelasi antar variabel bebas (independen). Model regresi yangbaik seharusnya tidak terjadi korelasi diantara variabel bebas. Korelasi sendiri adalah adanya derajat kekuatan hubungan antara dua variabel atau lebih. Jika variabel bebas saling berkorelasi, maka variabelvariabel ini tidak orthogonal. Maksud dari orthogonal disini adalah variabel bebas yang nilai korelasi antarsesama variabel bebas sama dengan nol(Ghozali, 2005:91).

Untuk mendeteksi ada atau tidaknya multikolinearitas di dalam model regresi, yakni dengan melihat dari nilai tolerance, dan lawannya yaitu varianceinflation factor (VIF). Kedua ukuran ini menunjukkan setiap variabel bebas manakah yang dijelaskan oleh variabel bebas lainnya.Tolerance mengukur variabilitas variabel bebas yang terpilih yang tidak dijelaskan oleh variabel bebaslainnya. Jadi, nilai tolerance yang rendah sama dengan nilai VIF yang tinggi(karena VIF $=1 /$ Tolerance). Nilai $c u t$ off yang umum dipakai untuk menunjukkanadanya multikolinearitas adalah nilai tolerance $<0,10$, atau sama dengan nilai VIF $<10$ (Ghozali, 2005:92). Apabila di dalam model regresi tidak ditemukanasumsi deteksi seperti di atas, maka model regresi yang digunakan dalampenelitian ini bebas dari multikolinearitas, dan demikian pula sebaliknya. 


\section{Uji Heteroskedastisitas}

Uji heteroskedastisitas bertujuan menguji apakah dalam model regresi terjadi ketidaksamaan varience dari residual satu pengamatan ke pengamatan yang lain. Jika varience dari residual satu pengamatan ke pengamatan yang lain tetap, maka disebut homokesdatisitas dan jika berbeda disebut heterokedastisitas. Model regresi yang baik adalah homokesdatisitas atau tidak terjadi heterokedastisitas, (Ghozali, 2005:105).

Pengujian heterokedastisitas dengan melihat grafik plot antara nilai prediksi variabel (ZPRED) dengan residual (SRESID). Dasar-dasar analisis:

a. Jika ada pola tertentu seperti titik-titik yang ada membantu pola tertentu yang teratur (bergelombang, melebar kemudian menyempit), maka mengindikasikan telah terjadi heteroskedastisitas.

b. Jika tidak ada pola yang jelas, serta titik-titik menyebar diatas dan dibawah 0 pada sumbu $\mathrm{Y}$, maka tidak terjadi heterokedastisitas.

\section{Uji Normalitas}

Uji normalitas dilakukan untuk menguji apakah dalam model regresi, variabel pengganggu atau residual memiliki distribusi normal. Model regresi yangbaik adalah berdistribusi normal atau mendekati normal. Untuk mengetahui ada tidaknya normalitas dalam model regresi, yaitu dengan melihat normal probability plot yang membandingkandistribusi komulatifdari distribusi normal. Distribusi normal akan membentuk satu garis lurus diagonal, dan ploting data residual akan dibandingkan dengan garis diagonal. Jikadistribusi data residual normal, maka garis yang menggambarkan data sesungguhnya akan mengikuti garis diagonalnya (Ghozali, 2005:110).

Pada prinsipnya normalitas dapat dideteksi dengan melihat penyebaran data (titik) pada sumbu diagonal dari grafik atau dengan melihat histogram dari residualnya. Adapun dasar pengambilan keputusan sebagai berikut (Ghozali, 2005:110):

1. Jika data menyebar di sekitar garis diagonal dan mengikuti arah garisdiagonal, maka model regresi memenuhi normalitas.

2. Jika data menyebar jauh dari garis diagonal dan tidak mengikuti arah garisdiagonal, maka model regresi tidak memenuhi normalitas.

Uji normalitas dengan grafik dapat menyesatkan karena secaravisualdapat kelihatan tidak normal padahal secara statistik bisa sebaliknya.Adapun ujinormalitas dengan statistik dapat digunakan melalui ujiKolmogorov-Smirnov $(K S$ test $)$, yaitu dengan melihat angkaprofitabilitassignifikan dimana data dapat disimpulkan berdistribusi normaljika angkasignifikansinya lebih besar dari 0,05.

\section{Analisis Statistik}

\section{Analisis Linear Berganda}

Dalam penelitian ini, penulis menggunakan formula dari model Regresi Linear Berganda. Karena menggunakan lebih dari satu variabel independen yang mempunyai pengaruh langsung terhadap variabel dependen. Regresi Berganda digunakan bila ingin meramalkan bagaimana keadaan variabel independen terhadap variabel dependen. Adapun rumus analisis linear berganda sebagai berikut:

Keterangan:

$$
\mathrm{Y}=\mathrm{a}+\beta_{1} \mathrm{X}_{1}+\beta_{2} \mathrm{X}_{2}
$$

$$
\mathrm{Y}=\text { Kinerja Pegawai }
$$


$\mathrm{a}=$ Konstanta

$\mathrm{X}_{1}=$ Disiplin Kerja

$\mathrm{X}_{2}=$ Pengalaman Kerja

$\beta_{1}, \beta_{2}=$ Koefisien garis regresi

\section{Uji Hipotesis}

\section{Uji Hipotesis Secara Parsial (Uji t)}

Uji $t$ digunakan untuk menguji signifikansi hubungan antara variabel $\mathrm{X}$ dan $\mathrm{Y}$, apakah variabel $\mathrm{X}_{1}$ dan $\mathrm{X}_{2}$ (disiplin kerja dan pengalaman kerja) benar-benar berpengaruh terhadap variabel $\mathrm{Y}$ (kinerja pegawai) secara terpisah atau parsial (Ghozali, 2005). Hipotesis yang digunakan dalam pengujian ini adalah:

$\mathrm{H}_{01}$ : Tidak ada pengaruh yang signifikan antara disiplin kerja terhadap kinerja pegawai di Kantor Badan Pusat Statistik Kabupaten Labuhanbatu.

$\mathrm{H}_{\mathrm{a} 1}$ : Ada pengaruh yang signifikan antara disiplin kerja terhadap kinerja pegawai di kantor Badan Pusat Statistik Kabupaten Labuhanbatu.

$\mathrm{H}_{02}$ : Tidak ada pengaruh yang signifikan antara pengalaman kerja terhadap kinerja pegawai di kantor Badan Pusat Statistik Kabupaten Labuhanbatu.

$\mathrm{H}_{\mathrm{a} 2}$ : Ada pengaruh yang signifikan antara pengalaman kerja terhadap kinerja pegawai di kantor Badan Pusat Statistik Kabupaten Labuhanbatu.

Adapun rumus uji $t$ (t-tes) menurut Rumus : Sugiyono (2008) sebagai berikut:

$$
t=\frac{R \sqrt{n-2}}{\sqrt{1-R^{2}}}
$$

Keterangan : $\mathrm{R}$ : Koefisien Korelasi

$$
\begin{aligned}
& \mathrm{R}^{2} \text { : Koefisien Determinasi } \\
& \mathrm{n} \text { : Banyaknya sampel }
\end{aligned}
$$

Dasar pengambilan keputusan (Ghozali, 2005) adalah dengan menggunakan perbandingan nilai t hitung dengan $t$ tabel, yaitu:

- Apabila nilai $\mathrm{t}$ hitung $<\mathrm{t}$ tabel, maka Ho diterima dan Ha ditolak.

- Apabila nilait hitung $>\mathrm{t}$ tabel, maka Ho ditolak dan Ha diterima.

\section{Uji Hipotesis Secara Simultan (Uji F)}

Dalam penelitian ini, uji $F$ digunakan untuk mengetahui tingkat siginifikansi pengaruh variabel-variabel independen secara bersama-sama (simultan) terhadap variabel dependen (Ghozali, 2005). Dalam penelitian ini, hipotesis yang digunakan adalah:

$\mathrm{H}_{03}$ : Tidak ada pengaruh disiplin kerja dan pengalaman kerjaterhadap kinerja pegawai di kantor Badan Pusat Statistik Kabupaten Labuhanbatu.

$\mathrm{H}_{\mathrm{a} 3}$ : Ada pengaruh disiplin kerja dan pengalaman kerjaterhadap kinerja pegawai di kantor Badan Pusat Statistik Kabupaten Labuhanbatu. Untuk mengetahui pengaruh variabel bebas terhadap variabel terikat menggunakan Uji $\mathrm{F}$ dengan rumus menurut Supranto (2011) adalah:

$$
F_{0}=\frac{R^{2} /(k-1)}{1-R^{2} /(n-k)}
$$

Dasar pengambilan keputusannya (Ghozali, 2005) adalah dengan menggunakan perbandingan nilai $\mathrm{F}$ hitung dengan $\mathrm{F}$ tabel, yaitu:

- Apabila nilai $\mathrm{F}$ hitung< $\mathrm{F}$ tabel, maka Ho diterima dan Ha ditolak.

- Apabila nilai F hitung $>$ F tabel, maka Ho ditolak dan Ha diterima.

\section{Analisis Koefisien Determinasi $\left(\mathbf{R}^{2}\right)$}

Koefisien determinasi $\left(\mathrm{R}^{2}\right)$ pada intinya mengukur seberapa jauh kemampuan model dalam menerangkan 
variasi variabel terikat (Ghozali, 2005). Nilai Koefisien determinasi adalah antara nol dan satu. Nilai $\mathrm{R}^{2}$ yang kecil berarti kemampuan variabel-variabel bebas (motivasi, disiplin kerja dan pengalaman kerja) dalam menjelaskan variasi variabel terikat (kinerja pegawai) amat terbatas. Begitu pula sebaliknya, nilai yang mendekati satu berarti variabel-variabel bebas memberikan hampir semua informasi yang dibutuhkan untuk memprediksi variasi variabel terikat. Adapun cara perhitungan Koefisien Determinasi $\left(\mathrm{R}^{2}\right)$ dengan rumus:

$$
\mathrm{KD}=R^{2} \times 100 \%
$$

Keterangan :

KD:Koefisien Determinasi

$\mathrm{R}$ : Koefisien Korelasi

\section{HASIL DAN PEMBAHASAN}

\section{Hasil Uji Penyimpangan Klasik}

\section{Hasil Uji Multikolinearitas}

Untuk dapat menentukan apakah terdapat multikolinearitas dalam model regresi pada penelitian ini adalah dengan melihat nilai VIF (Variance Inflation Factor) dan tolerance serta menganalisis matrix korelasi variabel-variabel bebas. Adapun nilai VIF dapat dilihat pada tabel dibawah ini :

\section{Uji Multikolinearitas}

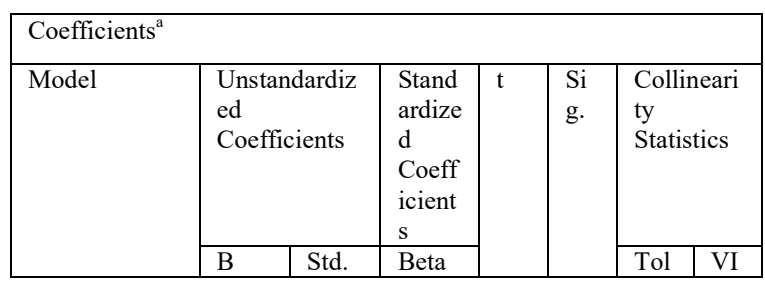

\begin{tabular}{|c|c|c|c|c|c|c|c|c|}
\hline & & Error & & & & $\begin{array}{l}\text { era } \\
\text { nce }\end{array}$ & $\mathrm{F}$ \\
\hline \multirow[t]{3}{*}{1} & (Constant & $\begin{array}{l}29.2 \\
70\end{array}$ & $\begin{array}{l}8.37 \\
4\end{array}$ & & $\begin{array}{l}3.4 \\
96\end{array}$ & $\begin{array}{l}.00 \\
2\end{array}$ & & \\
\hline & $\begin{array}{l}\text { Disiplin } \\
\text { Kerja }\end{array}$ & .352 & .180 & .341 & $\begin{array}{l}4.3 \\
89\end{array}$ & $\begin{array}{ll}.00 \\
3\end{array}$ & $\begin{array}{l}.80 \\
0\end{array}$ & $\begin{array}{l}1.2 \\
49 \\
\end{array}$ \\
\hline & $\begin{array}{l}\text { Pengalam } \\
\text { an Kerja }\end{array}$ & .329 & .222 & .320 & $\begin{array}{l}5.5 \\
82\end{array}$ & $\begin{array}{l}.00 \\
6 \\
\end{array}$ & $\begin{array}{l}.79 \\
6 \\
\end{array}$ & $\begin{array}{l}1.2 \\
56\end{array}$ \\
\hline \multicolumn{4}{|c|}{$\begin{array}{l}\text { a. Dependent Variable: Kinerja } \\
\text { Pegawai }\end{array}$} & & & & & \\
\hline
\end{tabular}

Sumber: Data diolah

Dari tabel terlihat bahwa dari hasil tersebut menunjukkan bahwa semua nilai VIF dari variabel independent memiliki nilai yang lebih kecil dari 10. Hasil pengujian model regresi tersebut menunjukkan tidak adanya gejala multikolinier dalam model regresi. Hal ini berarti bahwa semua variabel independent tersebut layak digunakan sebagai predictor.

\section{Hasil Uji Heteroskedastisitas}

Uji heteroskedastisitas bertujuan untuk menguji apakah dalam model regresi terjadi ketidaksamaan varian dari satu pengamatan ke pengamatan yang lain.

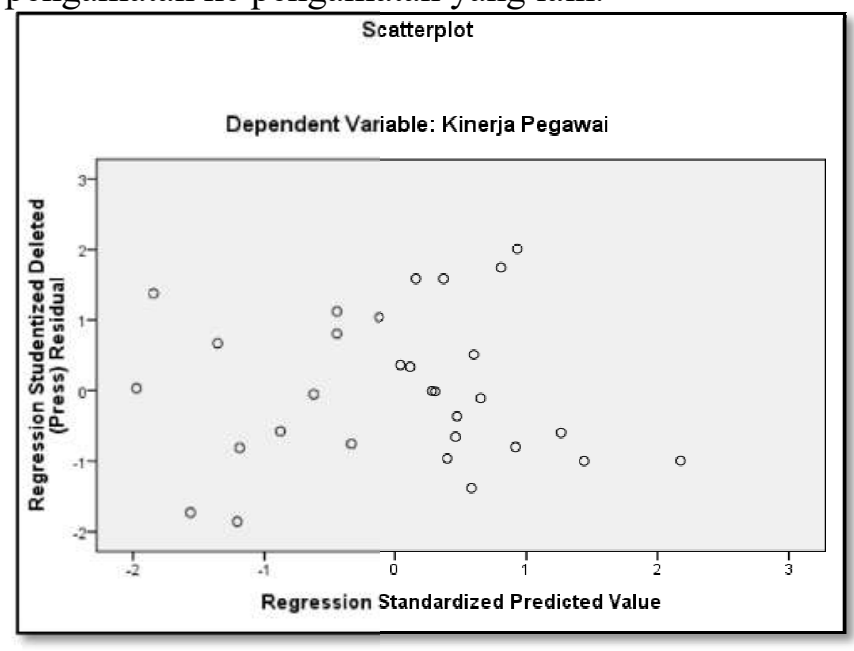

Uji Heteroskedastisitas 
Hasil pengujian heteroskedastisitas menunjukkan bahwa titik-titik tidak membentuk pola tertentu atau tidak ada pola yang jelas serta titik-titik menyebar di atas dan dibawah angka 0 (nol) pada sumbu Y, maka tidak terjadi heteroskedastisitas.

Hasil Uji Normalitas

Uji normalitas bertujuan untuk menguji apakah dalam sebuah model regresi, seluruh variabel yang digunakan dalam penelitian baik variabel dependen maupun variabel independen, mempunyai distribusi yang normal atau tidak normal dengan menggunakan grafik normal probability plot danuji Kolmogorov-Smirnov (KS test). Model regresi yang baik dan dapat dipergunakan adalah model regresi yang mempunyai distribusi normal atau mendekati normal. Hasil pengujian normalitas tampak dalam tabel berikut ini:

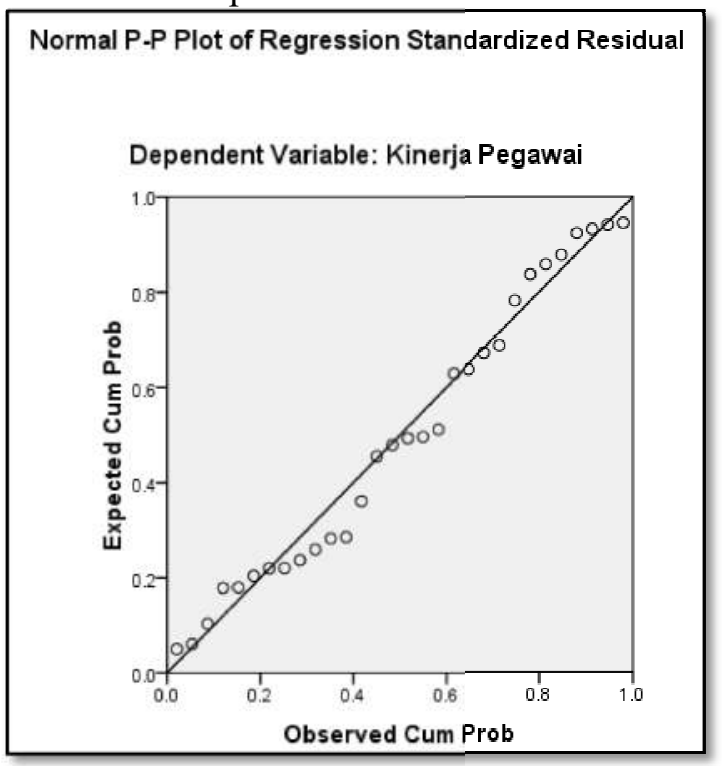

Grafik Normal Probability Plot

Dari Gambar dapat dilihat grafik normal probability plot menunjukkan bahwa data menyebar di sekitar garis diagonal dan mengikuti arah garis diagonal, sehingga dapat disimpulkan bahwa model regresi telah memenuhi asumsi normalitas.

\section{Hasil Analisis Statistik}

\section{Hasil Analisis Linear Berganda}

Analisis regresi linear berganda digunakan dalam penelitian ini dengan tujuan untuk mengetahui ada tidaknya pengaruh variabel bebas terhadap variabel terikat. Perhitungan statistik dalam analisis regresi linear berganda yang digunakan dalam penelitian ini adalah dengan menggunakan bantuan program komputer SPSS forWindows versi 20.0. Ringkasan hasil pengolahan data dengan menggunakan program SPSS tersebut adalah sebagai berikut :

\section{Hasil Analisis Linear Berganda}

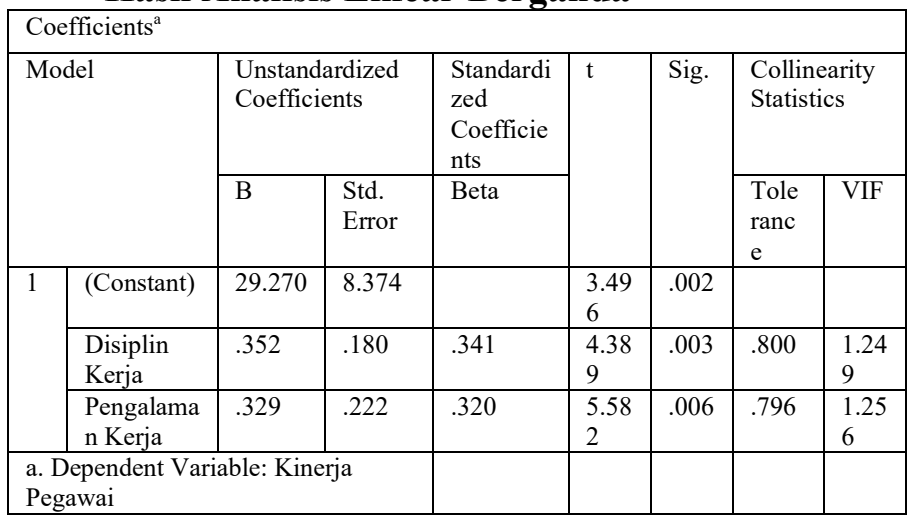

Sumber: Data diolah

Dari tabel di atas diperoleh model persamaan regresi yang dapat dituliskan dalam bentukpersamaan regresi sebagai berikut :

$$
\begin{aligned}
& \mathrm{Y}=29.270+0.352 \mathrm{X} 1+ \\
& 0.329 \mathrm{X}_{2}
\end{aligned}
$$


Persamaan regresi tersebut dapat dejelaskan sebagai berikut :

a. Konstanta sebesar 29.270 menunjukkan bahwa jika tidak ada variabel disiplin kerja dan pengalaman kerja, maka kinerja pegawai di kantor Badan Pusat Statistik Kabupaten Labuhanbatuadalah sebesar 29.270 persen.

b. Koefisien regresi variabel disiplin kerja sebesar 0.352 mempunyai arah positif dalampengaruhnya terhadap kinerja pegawai. Hal ini juga menunjukkan bahwa jika adanya disiplin kerja sebesar 1 Point, maka kinerja di kantor Badan Pusat Statistik Kabupaten Labuhanbatu akan naik sebesar 0.352 persen.

c. Koefisien regresi variabel pengalaman kerja sebesar 0.329 mempunyai arah positif dalam pengaruhnya terhadap kinerja pegawai. Hal ini juga menunjukkan bahwa jika adanya pengalaman kerja sebesar 1 Point, maka kinerja pegawai di kantor Badan Pusat Statistik Kabupaten Labuhanbatuakan naik sebesar 0.499 persen.

\section{Hasil Uji Hipotesis}

\section{Hasil Uji Hipotesis Secara Parsial (Uji t)}

Uji $t$ (t-test) ini dimaksudkan untuk mengetahui pengaruh secara parsial (individu) variabel-variabel bebas (disiplin kerja dan pengalaman kerja) terhadap variabel terikat (kinerja pegawai) atau menguji signifikansi konstanta dan variabel terikat. Hasil perhitungan uji $\mathrm{t}$ dapat dilihat pada tabel berikut ini:

\section{Hasil Uji Secara Parsial (Uji t)}

\begin{tabular}{|c|c|c|c|c|c|c|c|c|}
\hline \multicolumn{9}{|c|}{ Coefficients $^{\mathrm{a}}$} \\
\hline \multirow{2}{*}{\multicolumn{2}{|c|}{ Model }} & \multicolumn{2}{|c|}{$\begin{array}{l}\text { Unstandardiz } \\
\text { ed } \\
\text { Coefficients }\end{array}$} & \multirow{2}{*}{$\begin{array}{l}\text { Standa } \\
\text { rdized } \\
\text { Coeffi } \\
\text { cients } \\
\text { Beta }\end{array}$} & \multirow[t]{2}{*}{$\mathrm{t}$} & \multirow[t]{2}{*}{$\begin{array}{l}\mathrm{Si} \\
\mathrm{g} .\end{array}$} & \multicolumn{2}{|c|}{$\begin{array}{l}\text { Collineari } \\
\text { ty } \\
\text { Statistics }\end{array}$} \\
\hline & & B & $\begin{array}{l}\text { Std. } \\
\text { Erro } \\
\mathrm{r}\end{array}$ & & & & $\begin{array}{l}\text { Tol } \\
\text { era } \\
\text { nce }\end{array}$ & $\begin{array}{l}\text { VI } \\
\text { F }\end{array}$ \\
\hline \multirow[t]{3}{*}{1} & $\begin{array}{l}\text { (Consta } \\
\text { nt) }\end{array}$ & $\begin{array}{l}29.2 \\
70\end{array}$ & $\begin{array}{l}8.37 \\
4\end{array}$ & & $\begin{array}{l}3.4 \\
96 \\
\end{array}$ & $\begin{array}{l}.00 \\
2\end{array}$ & & \\
\hline & $\begin{array}{l}\text { Disiplin } \\
\text { Kerja }\end{array}$ & .352 & .180 & .341 & $\begin{array}{l}4.3 \\
89\end{array}$ & $\begin{array}{l}.00 \\
3 \\
\end{array}$ & $\begin{array}{l}.80 \\
0\end{array}$ & $\begin{array}{l}1.2 \\
49\end{array}$ \\
\hline & $\begin{array}{l}\text { Pengala } \\
\text { man } \\
\text { Kerja }\end{array}$ & .329 & .222 & .320 & $\begin{array}{l}5.5 \\
82\end{array}$ & $\begin{array}{l}.00 \\
6\end{array}$ & $\begin{array}{l}.79 \\
6\end{array}$ & $\begin{array}{l}1.2 \\
56\end{array}$ \\
\hline \multicolumn{4}{|c|}{$\begin{array}{l}\text { a. Dependent Variable: } \\
\text { Kinerja Pegawai }\end{array}$} & & & & & \\
\hline
\end{tabular}

Sumber: Data diolah

maka $\begin{array}{r}\text { Berdasarkan pada tabel diatas, } \\ \text { dapat }\end{array}$ mengenaipengujian hipotesis secara parsial yang telah dibuat sebelumnya sebagai berikut:

a. Disiplin Kerja

$\mathrm{H}_{0} 2=0$ : Tidak ada pengaruh yang signifikan antara disiplin kerja terhadap kinerja pegawai di kantor Badan Pusat Statistik Kabupaten Labuhanbatu.

\section{$\mathrm{H}_{\mathrm{a}} 2>0 \quad$ : Ada pengaruh yang} signifikan antara disiplin kerja terhadap kinerja pegawai di di kantor Badan Pusat Statistik Kabupaten Labuhanbatu.

Hasil pengujian dengan SPSS diperoleh untuk variabel $\mathrm{X}_{1}$ (Disiplin Kerja) diperoleh nilai t hitung $=4.389$. Dengan membandingkan thitung lebih besar dari t tabel $(4.389>1.701)$. Hal 
ini menjelaskan menunjukkan bahwa disiplin kerja memiliki pengaruh yang signifikan terhadap kinerja pegawai. Hal ini berarti Hipotesis alternatif 1 diterima. Arah koefisien regresi positif berarti bahwa disiplin kerja memiliki pengaruh positif yang signifikan terhadap kinerja pegawai. Semakin baik disiplin kerja yang ada di dalam diri pegawai akan semakin tinggi pula kinerja pegawai tersebut, sebaliknya semakin tidak rendah disiplin kerja yang ada di dalam diri pegawai semakin rendah pula kinerja pegawai.

b. Pengalaman Kerja

$\mathrm{H}_{02}=0$ : Tidak ada pengaruh yang signifikan antara pengalaman kerja terhadap kinerja pegawaidi kantor Badan Pusat Statistik Kabupaten Labuhanbatu.

$$
\begin{aligned}
& \mathrm{H}_{\mathrm{a} 2}>0 \text { : Ada pengaruh yang } \begin{array}{r}
\text { Ada antara } \\
\text { signifikan }
\end{array} \\
& \text { pengalaman kerja terhadap } \\
& \text { kinerja pegawai di kantor } \\
& \text { Badan Pusat Statistik } \\
& \text { Kabupaten Labuhanbatu. }
\end{aligned}
$$

Hasil pengujian dengan SPSS diperoleh untuk variabel $\mathrm{X}_{2}$ (Pengalaman Kerja) diperoleh nilai $\mathrm{t}$ hitung $=5.582$. Dengan membandingkan $t$ hitung lebih besar dari $t$ tabel $(5.582>1.701)$. Hal ini menjelaskan menunjukkan bahwa pengalaman kerja memiliki pengaruh yang signifikan terhadap kinerja pegawai. Hal ini berarti Hipotesis alternatif 2 diterima. Arah koefisien regresi positif berarti bahwa pengalaman kerja memiliki pengaruh positif yang signifikan terhadap kinerja pegawai. Semakin banyak pengalaman kerja seorang pegawai akan semakin tinggi pula kinerja pegawai tersebut, sebaliknya sedikit pengalaman kerja seorang pegawai semakin rendah pula kinerja pegawai.

\section{Hasil Uji Hipotesis Secara Simultan (Uji F)}

Pengujian terhadap pengaruh semua variabel independen di dalam model dapat dilakukan dengan uji simultan (uji F). Uji statistik $F$ pada dasarnya menunjukkan apakah semua variabel independen yang dimasukkan dalam model

\begin{tabular}{|c|c|c|c|c|c|c|}
\hline \multicolumn{7}{|c|}{ ANOVA $^{b}$} \\
\hline \multicolumn{2}{|c|}{ Model } & Sum of & df & Mean & $\mathrm{F}$ & Sig. \\
\hline \multirow[t]{3}{*}{1} & $\begin{array}{l}\text { Regress } \\
\text { ion }\end{array}$ & 25.963 & 3 & 8.654 & 6.742 & $.003^{\mathrm{a}}$ \\
\hline & Residua & 303.403 & 26 & 11.669 & & \\
\hline & Total & 329.367 & 29 & & & \\
\hline \multicolumn{6}{|c|}{ a. Predictors: (Constant), Pengalaman Kerja, Disiplin Kerja } & \\
\hline & ndent & ble: Kin & & & & \\
\hline
\end{tabular}
mempunyai pengaruh secara bersama-sama terhadap variabel dependen. Hasil perhitungan uji $\mathrm{F}$ dapatdilihat pada tabel berikut ini:

\section{Hasil Uji Secara Simultan (Uji F)}

Sumber: Data diolah

Dari uji $\mathrm{F}$ (ANOVA/Simultan) didapat nilai $F$ hitung sebesar 6.742 dan dibandingkan dengan nilai $\mathrm{F}$ tabel sebesar 4.21 dapat dilihat bahwa $\mathrm{F}$ hitung lebih besar dari $F$ tabel $(6.742>4.21)$, maka variabel disiplin kerja dan pengalaman kerja secara bersama-sama berpengaruh signifikan terhadap variabel kinerja pegawai di kantor Badan Pusat Statistik Kabupaten Labuhanbatu. 


\section{Hasil Analisis Koefisien Determinasi}

$\left(\mathbf{R}^{2}\right)$

$\begin{array}{rrr}\text { Koefisien determinasi } & \left(\mathrm{R}^{2}\right) \text { pada } \\ \text { intinya mengukur } & \text { seberapa } \\ \text { jauhkemampuan } & \text { model } & \text { dalam }\end{array}$
menerangkan variasi variabel dependen. Nilai koefisiendeterminasi adalah antara nol dan satu (Ghozali, 2005). Nilai koefisiendeterminasi dapat dilihat pada tabel dibawah ini:

\section{Hasil Koefisien Determinasi $\left(\mathbf{R}^{2}\right)$}

\begin{tabular}{|c|c|c|c|c|c|c|c|c|c|}
\hline \multicolumn{10}{|c|}{ Model Summary ${ }^{\mathrm{b}}$} \\
\hline \multirow{2}{*}{$\begin{array}{l}\mathrm{M} \\
\mathrm{o} \\
\mathrm{d} \\
\mathrm{e} \\
\mathrm{l}\end{array}$} & \multirow[t]{2}{*}{$\mathrm{R}$} & \multirow{2}{*}{$\begin{array}{l}\mathrm{R} \\
\mathrm{Sq} \\
\mathrm{ua} \\
\text { re }\end{array}$} & \multirow{2}{*}{$\begin{array}{c}\text { Adju } \\
\text { sted } \\
\text { R } \\
\text { Squa } \\
\text { re }\end{array}$} & \multirow[b]{2}{*}{$\begin{array}{c}\text { Std. } \\
\text { Erro } \\
\mathrm{r} \text { of } \\
\text { the } \\
\text { Esti } \\
\text { mate }\end{array}$} & \multicolumn{5}{|c|}{ Change Statistics } \\
\hline & & & & & $\begin{array}{c}\mathrm{R} \\
\text { Squa } \\
\text { re } \\
\text { Cha } \\
\text { nge }\end{array}$ & $\begin{array}{c}\mathrm{F} \\
\mathrm{Ch} \\
\text { an } \\
\text { ge }\end{array}$ & $\begin{array}{c}\mathrm{df} \\
1\end{array}$ & $\begin{array}{c}\mathrm{df} \\
2\end{array}$ & $\begin{array}{c}\text { Sig. } \\
\text { F } \\
\text { Cha } \\
\text { nge }\end{array}$ \\
\hline 1 & $\begin{array}{r}.6 \\
81 \\
\text { a }\end{array}$ & $\begin{array}{r}.4 \\
64\end{array}$ & .427 & $\begin{array}{r}3.41 \\
6\end{array}$ & .464 & $\begin{array}{r}6.7 \\
42\end{array}$ & 3 & 26 & .003 \\
\hline & $\mathrm{ia}, \mathrm{D}$ & pli & $\begin{array}{l}\text { onstan } \\
\text { erja }\end{array}$ & eng & ian & & & & \\
\hline & $\begin{array}{l}\text { epe } \\
\text { erja }\end{array}$ & nt & riable & & & & & & \\
\hline
\end{tabular}

Sumber: Data diolah

Dengan mengunakan rumus perhitungan koefisien determinasi $\left(\mathrm{R}^{2}\right)$ diperoleh besarnya pengaruh variabel dependen sebagai berikut:

$$
K D=R^{2} \times 100 \%
$$

Perhitungan :

$$
\begin{aligned}
& \mathrm{KD}=(0.681)^{2} \times 100 \% \\
& \mathrm{KD}=0.464 \times 100 \% \\
& \mathrm{KD}=46.4 \%
\end{aligned}
$$

Hasil perhitungandi atas dapat diketahui bahwa koefisien determinasi $\left(\mathrm{R}^{2}\right)$ yang diperoleh sebesar 0.464. Hal ini berarti $46.4 \%$ kinerja pegawai dapat dijelaskan oleh variabel disiplin kerja dan pengalaman kerja, sedangkan sisanya yaitu53.6\% kinerja pegawai dipengaruhi oleh variabel-variabel lainnya yang tidak diteliti dalam penelitian ini.

\section{Pembahasan}

\section{Pengaruh Disiplin Kerja $\left(\mathrm{X}_{1}\right)$ Terhadap Kinerja Pegawai (Y)}

Berdasarkan hasil perhitungan analisis regresi linear berganda dengan pengujian secara parsial diketahui bahwa variabel disiplin kerja $\left(\mathrm{X}_{2}\right)$ diperoleh koefisien sebesar 0.352 , $\mathrm{t}$ hitung $5.289>\mathrm{t}$ tabel 1.701 yang berarti jika variabel disiplin kerja meningkat maka akan berpengaruh terhadap kinerja pegawai di kantor Badan Pusat Statistik Kabupaten Labuhanbatu sebesar 0.352. Dengan kata lain kinerja pegawai akan meningkat sejalan dengan perbaikan pengalaman kerja pada pegawai di kantor Badan Pusat Statistik Kabupaten Labuhanbatu.Disiplin kerja yang baik mencerminkan besarnya rasa tanggung jawab seseorang terhadap tugas-tugas yang diberikan kepadanya. Dengan disiplin kerja pegawai yang tinggi, akan mampu mencapai efektivitas kerja yang maksimal, baik itu disiplin waktu, tata tertib atau peraturan yang telah ditetapkan oleh organisasi.

\section{Pengaruh Pengalaman Kerja $\left(\mathbf{X}_{2}\right)$ Terhadap Kinerja Pegawai (Y)}

Berdasarkan hasil perhitungan analisis regresi linear berganda dengan pengujian secara parsial diketahui bahwa variabel pengalaman kerja $\left(\mathrm{X}_{2}\right)$ diperoleh koefisien sebesar 0.329 , $\mathrm{t}$ hitung $4.582>\mathrm{t}$ tabel 1.701 yang berarti jika variabel pengalaman kerja meningkatkan maka akan berpengaruh terhadap kinerja pegawai di kantor Badan Pusat Statistik Kabupaten Labuhanbatu sebesar 0.329. Dengan kata lain kinerja pegawai akan meningkat sejalan dengan semakin lama pengalaman kerja para pegawai pada di 
kantor Badan Pusat Statistik Kabupaten Labuhanbatu. Pengalaman kerja pegawai mencerminkan tingkat penguasaan pengetahuan dan keterampilan yang dimiliki seorang pegawai dalam bekerja yang dapat diukur dari masa kerja dan jenis pekerjaan yang pernah dikerjakan pegawai. Masa kerja pegawai yang semakin lama dengan jumlah pegawai semakin sedikit menyebabkan kurangnya pengalaman kerja Pegawai.

\section{Pengaruh Disiplin Kerja $\left(\mathrm{X}_{1}\right)$ dan Pengalaman Kerja $\left(X_{2}\right)$ Terhadap Kinerja Pegawai (Y)}

Berdasarkan hasil perhitungan analisis regresi linear berganda dengan pengujian secara simultan diketahui bahwa variabel disiplin kerja $\left(\mathrm{X}_{1}\right)$ dan pengalaman kerja $\left(\mathrm{X}_{2}\right)$ diperoleh nilai $\mathrm{F}$ hitung $6.742>\mathrm{F}$ tabel 4.21yang berarti variabel disiplin kerja dan pengalaman kerja berpengaruhsecara simultan (bersamasama) terhadap kinerja pegawai di kantor Badan Pusat Statistik Kabupaten Labuhanbatu.

Dan dari uji koefisien determinasi diperoleh besarnya pengaruh disiplin kerja $\left(\mathrm{X}_{1}\right)$ dan pengalaman kerja $\left(\mathrm{X}_{2}\right)$ terhadap Kinerja Pegawai (Y) sebesar 46.4\% (sama dengan Koefisien determinasi) dan sisanya sebesar 53.6\% Kinerja Pegawaidi kantor Badan Pusat Statistik Kabupaten Labuhanbatu dipengaruhi faktor-faktor atau variabel yang lain diluar model regresi.

\section{DAFTAR PUSTAKA}

Bernardin, H.John and Russel. 2010. Human Resource Management. New York: McGraw-Hill

Davis, Keith dan Newstorm, J.W, 2005. Perilaku dalam Organisasi, Edisi
Kesebelas, Diterjemahkan oleh Agus Dharma, Penerbit: Erlangga, Jakarta. Hasibuan, SP Melayu. 2009. Organisasi dan Motivasi. Jakarta : Bumi Aksara.

Heidjerachman, 2007. "Manajemen Personalia". Edisi kedua, Cetakan Pertama, Penerbit BPFE UGM, Yogyakarta.

Imam Ghozali. 2005. Aplikasi Analisis Multivariate dengan Program SPSS. Semarang : Badan Penerbit Universitas Diponegoro.

Malayu Hasibuan S.P., (2007), Manajemen Sumber Daya Manusia. Cetakan Ketiga, Penerbit Bumi Aksara,Jakarta.

Mangkunegara, Anwar Prabu. 2011. Manajemen Sumber Daya Manusia Perusahaan. Bandung : PT. Remaja Rosdakarya.

Martoyo, Susilo. (2007). Manajemen Sumber Daya Manusia, Edisi 5, Cetakan Pertama. Yogyakarta: BPFE.

Nasaruddin, 2001. Argumentasi kesetaraan gender, Jakarta : Paramadina.

Rivai, Veithzal. 2008. Manajemen Sumber Daya Manusia untuk Perusahaan. Jakarta : Rajagrafindo Persada.

Robbins, Stephen P. 2008. Perilaku Organisasi. Jakarta : PT Indeks.

Supranto, J. 2011. Pengukuran Tingkat Kepuasan Pelanggan Untuk Menaikkan Pangsa Pasar, Cetakan keempat, Penerbit PT Rineka Cipta, Jakarta.

Samsudin, Sadili. 2010. Manajemen Sumber Daya Manusia, Bandung : Pustaka Setia.

Suprihanto John, dkk., (2008), Perilaku Organisasional, Sekolah Tinggi Ilmu Ekonomi YKPN,Yogyakarta. 
Waldman, D. A. (1994). The Contribution of Total Anality Management to a Theory of Work Performance. 19, 210-536.

Yuwalliatin, Sitty. 2006. Pengaruh Budaya Organisasi, Motivasi dan Komitmen Terhadap Kinerja Serta Pengaruhnya Terhadap Keunggulan Kompetitif Dosen Unissula Semarang. Jurnal Ekonomi dan Bisnis, Vol. 7 No. 2, Juli, p. 241-256. 